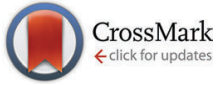

Cite this: New J. Chem., 2016, 40,2829

Received (in Montpellier, France) 23rd October 2015,

Accepted 21st January 2016

DOI: 10.1039/c5nj02957k

www.rsc.org/njc

\section{Perovskite solar cells fabricated using dicarboxylic fullerene derivatives $\dagger$}

\author{
Sule Erten-Ela, ${ }^{\text {abc }}$ Haiwei Chen, ${ }^{\mathrm{b}}$ Andreas Kratzer, ${ }^{\mathrm{c}}$ Andreas Hirsch ${ }^{\mathrm{c}}$ and \\ Christoph J. Brabec ${ }^{b}$
}

\begin{abstract}
Perovskite solar cells were first fabricated in dye sensitized solar cells. But also, perovskite hybrid solar cells were demonstrated to be among the most promising candidates within the emerging photovoltaic materials with their high power conversion efficiencies and low-cost fabrication. In this work, we design and synthesize a novel benzoic acid fullerene bis adduct material (BAFB) for use in perovskite hybrid organic-inorganic solar cells. The obtained maximum efficiency is reported to be $9.63 \%$ using a novel benzoic acid fullerene bis adduct (BAFB) for perovskite heterojunction solar cells.
\end{abstract}

\section{Introduction}

Perovskite heterojunction solar cells have attracted considerable attention recently because of their high solar cell efficiency besides their unique properties such as high absorption coefficient, excellent ambipolar charge mobility and small exciton binding energy. ${ }^{1-10}$ Kojima et al., first published liquid electrolyte dye sensitized solar cells of perovskite materials with $3.8 \%$ PCE solar cell efficiency. ${ }^{1}$ Then, solid state dye sensitized solar cell efficiency was reported to be $10 \%$. And today perovskite solar cells are known as highly efficient solar cells. The power conversion efficiencies (PCE) of organometal halide perovskite solar cells have increased from $3.8 \%$ to $20.1 \%$. In other words, the power conversion efficiencies of perovskite solar cells have increased in the past five years. They are highly efficient for new generation organic photovoltaic technology because the efficiency of perovskite solar cells match the efficiency of commercialized crystalline Si solar cells. ${ }^{11-19}$ The first perovskite solar cells were implemented in dye sensitized solar cells. But, perovskites have also been applied to heterojunction solar cells in low temperature solution processes. The configuration is quite similar to organic photovoltaic cells, which consist of easy solution processed fabrication techniques. Planar structured perovskite solar cells were fabricated with the efficiency of $10 \%$ by controlling interface engineering. The planar structure is a facile fabrication for low temperature solution processed solar cells. ${ }^{20-25}$ The preparation of

\footnotetext{
${ }^{a}$ Institute of Solar Energy, Ege University, Izmir, 35100, Turkey.

E-mail: suleerten@yahoo.com, sule.erten@ege.edu.tr; Tel: +90 2323111231

${ }^{b}$ Institute of Materials for Electronics and Energy Technology (I-MEET),

Department of Materials Science and Engineering, Friedrich-Alexander-University

Erlangen, Martensstrasse 7, Erlangen, Germany

' Institute of Organic Chemistry II, University of Erlangen-Nürnberg, Henkestr. 42, 91054 Erlangen, Germany

$\dagger$ Electronic supplementary information (ESI) available. See DOI: 10.1039/c5nj02957k
}

mesoporous $\mathrm{TiO}_{2}$ is omitted in the planar heterojunction device structure. ${ }^{25-30}$ In the planar structure, mesoporous $\mathrm{TiO}_{2}$ replaces the hole transport PEDOT:PSS layer, and hole transport spiro-OMETAD replaces the PCBM layer. A perovskite light absorbing layer is sandwiched between the hole- and electron transporting layers in the planar heterojunction perovskite solar cells. It is very important to control the carrier behaviours and the interface in the whole perovskite solar cells. ${ }^{30,31}$ The PEDOT:PSS layer is commonly used as the hole transport layer in heterojunction solar cells due to its good conductivity and solution processability. Although the mesoporous $\mathrm{TiO}_{2}$ based solid state perovskite solar cells employ the most efficient solar cells, this type of solar cells needs a high temperature sintering process at $450{ }^{\circ} \mathrm{C}$. This high temperature process effects the cost production of new generation solar cells and prevents the application in plastic substrates. For this reason, planar heterojunction perovskite solar cells supply an alternative approach for efficient perovskite solar cells with the sandwich geometry between the hole transport layer PEDOT:PSS and the electron transport layer $[6,6]$-phenyl$\mathrm{C}_{61}$-butyricacid methyl ester (PCBM). This alternative fabrication provides facile operation of solution processed perovskite solar cells. However, the alternative heterojunction perovskite solar cells have not yet reached the device efficiency of the conventional high temperature process. One developing step in planar perovskite heterojunction solar cells is to find a good electron acceptor fullerene material instead of the PCBM material to control the surface passivation of perovskite and interface properties. ${ }^{32,33}$ For this reason, novel benzoic acid fullerene bis adducts (BAFB) were designed and synthesized for planar heterojunction perovskite solar cells in this paper. Optoelectronic, electrochemical and photovoltaic properties of novel fullerene materials have been studied. Novel benzoic acid fullerene bis adducts (BAFB) pay significantly more attention for engineering perovskite heterojunction solar cells to passivate the defects on the surface and 
grain boundaries of perovskite films. Our photovoltaic results show that the benzoic acid fullerene bis adduct (BAFB) compound is highly promising for the application in heterojunction perovskite solar cells because of its close solar cell efficiency to the PCBM material.

\section{Experimental section}

\section{Materials}

All chemicals and solvents obtained from the suppliers were used without further purification. Reactions were monitored by thin layer chromatography using a Merck TLC silica gel $60 \mathrm{~F}_{254}$. Chromatography on the silica gel was performed over a Merck silica gel 60 (particle size: 0.040-0.063 mm, 230-400 mesh ASTM).

\section{Characterization}

NMR spectroscopy was conducted using a Bruker Avance 300 spectrometer. NMR-solvents were purchased from Deutero. The chemical shifts are reported in part per million (ppm) and referenced to the residual solvent. Spectral splitting patterns are designated as "s" (singlet), "d" (doublet), and "m" (multiplet). The raw data was processed using a MestReNova Lite.

Mass spectrometry (MS) was done on a Shimadzu AXIMA Confidence MALDI-TOF MS-spectrometer (nitrogen UV-laser, $50 \mathrm{~Hz}, 337 \mathrm{~nm}$ ). ESI mass spectrometry was carried out on a Bruker maxis 4G UHR TOF MS/MS-spectrometer.

${ }^{1} \mathrm{H}$ NMR spectra were recorded on a Bruker DPX $300(300 \mathrm{MHz})$ spectrometer and chemical shifts are reported as $\delta$ values (ppm) and referenced to residual ${ }^{1} \mathrm{H}$ signals in deuterated solvents.

Absorption profiles were recorded using a Perkin-Elmer Lambda-35 absorption spectrometer from 350 to $1100 \mathrm{~nm}$. CV measurements were performed using a Metrohm $\mu$ Autolab III/FRA2 potentiostat/galvanostat.

\section{Synthetic details}

4-Carboxybenzaldehyde (0.100 g, $0.666 \mathrm{mmol}, 2.0$ eq. $), \mathrm{C}_{60}$ ( $0.240 \mathrm{~g}, 0.333 \mathrm{mmol}, 1.0 \mathrm{eq}$.), and sarcosine $(0.059 \mathrm{~g}, 0.333 \mathrm{mmol}$, 2.0 eq.) were refluxed overnight under an argon atmosphere in dry toluene $(200 \mathrm{~mL})$. The solvent was removed by rotary evaporation under reduced pressure. The crude product was filtered and subsequently purified by column chromatography $\left(\mathrm{SiO}_{2}\right.$, toluene $\rightarrow$ toluene/THF $2: 1$ ) to afford a bright brown solid (111 mg, $0.103 \mathrm{mmol}, 31 \%$ ). Molecular structure of synthesized material was presented in Fig. 1. Also synthetic route was given in Fig. 2.

${ }^{1} \mathrm{H}-\mathrm{NMR}\left(\mathrm{CDCl}_{3}, 400 \mathrm{MHz}\right): \delta[\mathrm{ppm}]=2.78(\mathrm{~s}), 3.5-3.5(\mathrm{~m})$, $3.62-3.67(\mathrm{~m}), 3.79-3.82(\mathrm{~m}), 4.25-4.27(\mathrm{~m}), 4.43-4.46(\mathrm{~m}), 4.97-$ 4.99(m), 7.85-7.93(m), 8.09-8.11(m).

${ }^{13} \mathrm{C}-\mathrm{NMR}\left(\mathrm{CDCl}_{3}, 100 \mathrm{MHz}\right): \delta[\mathrm{ppm}]=39.9,61.7,64.2,69.1$, 69.2, 70.0, 70.3, 70.5, 70.6, 70.6, 72.5, 83.1, 129.4, 130.1, 130.3, $135.7,136.0,136.5,137.0,139.6,140.0,140.3,140.3,141.6$, $141.8,141.9,142.0,142.1,142.1,142.2,142.3,142.5,142.6$, $142.8,143.1,143.2,144.4,144.5,144.6,144.8,145.3,145.3$, $145.4,145.4,145.5,145.6,145.6$, 145.8, 145.9, 146.0, 146.2, 146.2 , 146.3, 146.3, 146.6, 147.4, 147.4, 152.8, 153.0, 153.9, 156.1, 166.4 .

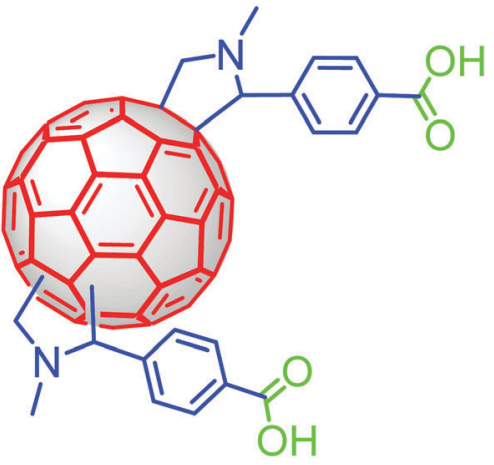

Fig. 1 Molecular structure of benzoic acid fullerene bis adducts (BAFB).

IR (ATR, diamond): $\left[\mathrm{cm}^{-1}\right]=3446,2945,2872,2780,1717$, 1700, 1611, 1275, 1099, 668.

UV/Vis $\left(\mathrm{CH}_{2} \mathrm{Cl}_{2}\right): \lambda_{\max }=228,264(\mathrm{sh}), 430 \mathrm{~nm}$.

MS (MALDI, dctb): $m / z=1074\left[\mathrm{M}^{+}\right]$.

HRMS (APPI, toluene): calcd. for $\mathrm{C}_{80} \mathrm{H}_{22} \mathrm{~N}_{2} \mathrm{O}_{4}\left[\mathrm{M}^{+}\right]$: 1074.18986, found: 1074.1574.

${ }^{1} \mathrm{H}$ NMR, ${ }^{13} \mathrm{C}$ NMR and mass spectra of BAFB are available in the $\mathrm{ESI} \dagger$.

\section{Electrochemistry}

Cyclic voltammetry measurement of novel fullerene dicarboxylic fullerene derivatives was taken by using a CH-Instrument $660 \mathrm{~B}$ Model Potentiostat equipment. An $o$-DCB/MeCN (4:1) solution mixture was used. A solution was prepared at $10^{-3} \mathrm{M}$ in this solution mixture. A three electrode-cell was used consisting of a glassy carbon working electrode, a Pt wire counter electrode and an $\mathrm{Ag} / \mathrm{AgCl}$ reference electrode, all placed in a glass vessel. Tetrabutylammoniumhexafluorophosphate $\left(\mathrm{TBAPF}_{6}\right), 0.1 \mathrm{M}$, was used as a supporting electrolyte. Ferrocene was used as an internal reference electrode.

\section{Perovskite solar cell device characterization}

$J-V$ curves were measured using a source measurement unit from Bo-Test with a Newport Sol1A solar simulator. The EQE spectra were measured using an Enli Technology (Taiwan) EQE measurement system (QE-R). A special mask was used to define the active area in the devices and measurements were carried out using this special mask. Reproducibility of measurements was checked many times for accuracy and precision.
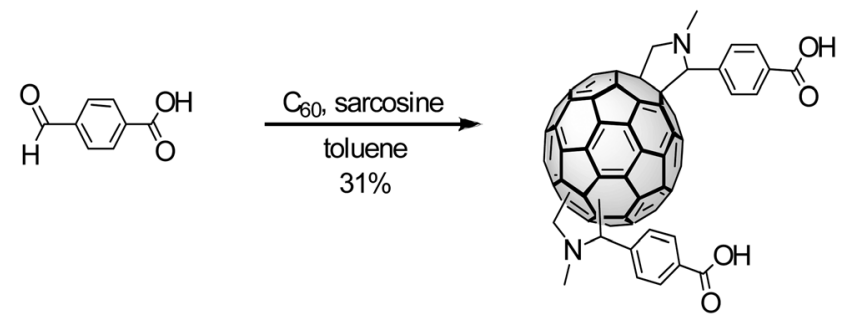

Fig. 2 Synthetic procedure of benzoic acid fullerene bis adduct (BAFB) derivatives. 


\section{Materials and preparation}

PEDOT:PSS and $\mathrm{PC}_{61} \mathrm{BM}$ (99.5\%) were purchased from Clevious and Solenne $\mathrm{BV}$, respectively. $\mathrm{PbI}_{2}$ and methyl ammonium iodide $\left(\mathrm{CH}_{3} \mathrm{NH}_{3} \mathrm{I}\right)$ were purchased from Sigma Aldrich and Dyenamo, respectively.

\section{Device fabrication}

Patterned ITO glass plates were sequentially ultrasonically cleaned with acetone and isopropanol for 20 minutes. Then, the cleaned ITO substrates were spin-coated with PEDOT:PSS and followed by annealing at $140{ }^{\circ} \mathrm{C}$ for $10 \mathrm{~min}$ in ambient air. $\mathrm{PbI}_{2}$ and $\mathrm{CH}_{3} \mathrm{NH}_{3} \mathrm{I}$ were mixed in a mixture of DMF and DMSO $(2: 1 \mathrm{v} / \mathrm{v})$ with a molar ratio of $1: 1$ with a concentration of $40 \mathrm{wt} \%$. The solution was spin-coated on to the ITO/PEDOT substrate at $4000 \mathrm{rpm}$ for $35 \mathrm{~s}$. Then, the substrates were annealed at $100{ }^{\circ} \mathrm{C}$ for 10 minutes. After that, $10 \mathrm{mg} \mathrm{ml} \mathrm{m}^{-1}$ BAFB and PCBM in chlorobenzene solution were dissolved overnight then the solutions were filtered using a $0.45 \mu \mathrm{m}$ pore size filter. Filtered solutions were coated on to the perovskite layer at $1000 \mathrm{rpm}$ for $30 \mathrm{~s}$. Subsequently, ZnO solution (nanoparticle suspensions, provided by NanoGrade) was deposited by spin-coating at $2000 \mathrm{rpm}$. The work function of $\mathrm{ZnO}$ is closer to the $\mathrm{Ag}$ metal electrode work function, and n-type $\mathrm{ZnO}$ was used for better electron injection to the Ag electrode. Finally, $100 \mathrm{~nm}$ $\mathrm{Ag}$ were thermally evaporated on top. The active area of this electrode is $10.4 \mathrm{~mm}^{2}$.

\section{Results and discussion}

\section{Optical and electrochemical properties of BAFB}

The optical absorption spectra of benzoic acid fullerene bis adducts (BAFB) were recorded in chlorobenzene solution at $25{ }^{\circ} \mathrm{C}$ as shown in Fig. 3. Absorption of the benzoic acid fullerene bis adduct (BAFB) compound displayed a typical bis adduct derivative absorption pattern at $311 \mathrm{~nm}$ that shows weak absorption in the visible region and the band offset ended at $450 \mathrm{~nm}$.

Cyclic voltammogram of benzoic acid fullerene bis adduct (BAFB) derivatives is shown in Fig. 4. The table of reduction

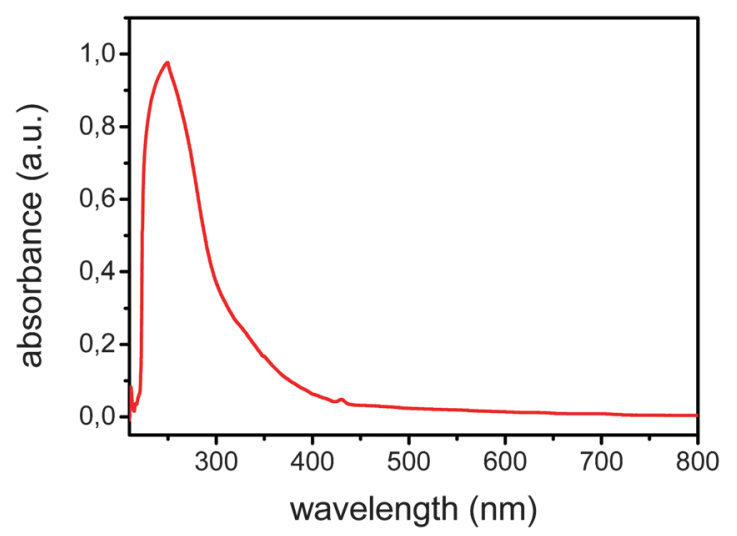

Fig. 3 Absorbance spectra of benzoic acid fullerene bis adduct (BAFB) derivatives in chlorobenzene in DCM.

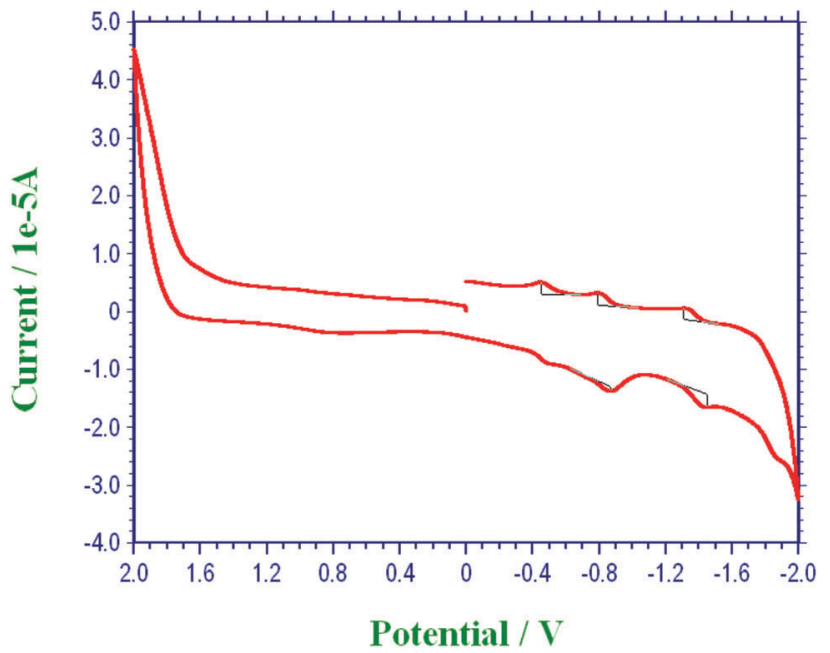

Fig. 4 Cyclic voltammetry measurements of benzoic acid fullerene bis adduct (BAFB) derivatives.

potentials of benzoic acid fullerene bis adduct (BAFB) derivative is presented in Table 1 . Cyclic voltammogram of BAFB was taken in an $o$-DCB/MeCN $(4: 1)$ solution mixture. Also, PCBM was taken under the same conditions for better comparison of reduction potentials. The lowest unoccupied molecular orbital,

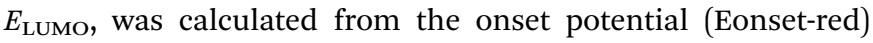
obtained from cyclic voltammogram (Fig. 4). The $E_{\text {LuMO }}$ energy level of BAFB is $3.86 \mathrm{eV}$, which is raised by $0.04 \mathrm{eV}$ in comparison to that of PCBM $(3.90 \mathrm{eV})$ under the same conditions. Our results show that the LUMO level of novel synthesized fullerene derivative, BAFB, is only $0.04 \mathrm{eV}$ lower than the PCBM material. The results show that this LUMO value is enough like the PCBM material for better electron transfer processes for perovskite solar cells. A schematic energy diagram is also presented in Fig. 5.

\section{Photovoltaic performances}

After investigation of the cyclic voltammogram of novel benzoic acid fullerene bis adducts (BAFB), the $E_{\text {LUMO }}$ level of BAFB was determined to be $3.86 \mathrm{eV}$, which is raised by $0.04 \mathrm{eV}$ in comparison to that of PCBM $(3.90 \mathrm{eV})$. We constructed a perovskite bulk heterojunction solar cell device using BAFB materials and PCBM as a reference cell under the same conditions. The device architecture consists of an indium doped tin oxide (ITO)-coated glass, spincoated PEDOT:PSS, a perovskite absorber, benzoic acid fullerene bis adducts (BAFB), and a ZnO layer with an evaporated silver contact ITO/PEDOT:PSS/perovskite/BAFB/ZnO/Ag. The current-voltage $(J-V)$ curve of the perovskite bulk heterojunction solar cells is presented in Fig. 6. Detailed solar cell performance parameters are summarized in Table 2. The perovskite bulk

Table 1 Redox potentials of benzoic acid fullerene bis adduct (BAFB) derivatives

\begin{tabular}{llll}
\hline & $E_{\text {red }}^{1}(\mathrm{~V})$ & $E_{\text {red }}^{2}(\mathrm{~V})$ & $E_{\text {red }}^{3}(\mathrm{~V})$ \\
\hline BAFB & -0.47 & -0.83 & -1.38 \\
PCBM & -0.43 & -0.82 & -1.33
\end{tabular}




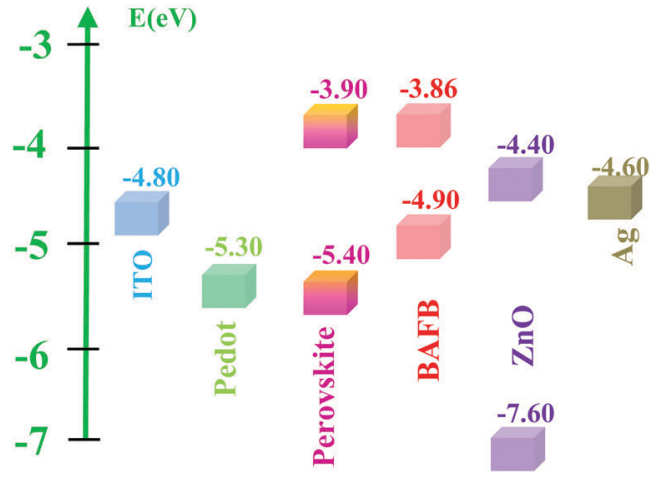

Fig. 5 Energy level diagrams of perovskite solar cells from the electrochemical data in Table 1.

heterojunction solar cells were prepared in an ITO/PEDOT:PSS/ perovskite layer/benzoic acid fullerene bis adducts (BAFB)/ZnO/ $\mathrm{Ag}$ device geometry. Also the reference cell was prepared in an ITO/PEDOT:PSS/perovskite layer/PCBM/ZnO/Ag device geometry. The efficiency of the reference cell displayed a short circuit current density $\left(J_{\text {sc }}\right)$ of $15.3 \mathrm{~mA} \mathrm{~cm} \mathrm{~cm}^{-2}$, an open circuit voltage of $0.87 \mathrm{~V}$, a fill factor of $76.40 \%$ and leading to an overall maximum power conversion efficiency of $10.27 \%$. The perovskite heterojunction solar cells using benzoic acid fullerene bis adducts (BAFB) presented an overall maximum power conversion efficiency of $9.63 \%$, a short circuit current density $\left(J_{\mathrm{sc}}\right)$ of $16.2 \mathrm{~mA} \mathrm{~cm}{ }^{-2}$, an open circuit voltage of $0.82 \mathrm{~V}$, and a fill factor of $69.1 \%$. The short circuit current density, $J_{\mathrm{sc}}$, of benzoic acid fullerene bis adduct (BAFB) based perovskite heterojunction solar cells is $16.2 \mathrm{~mA} \mathrm{~cm} \mathrm{~cm}^{-2}$. This value is 1.05 times higher than PCBM based perovskite heterojunction solar cells $\left(15.3 \mathrm{~mA} \mathrm{~cm}{ }^{-2}\right)$. However, the fill factor of the PCBM based device was found to be $76.40 \%$. Whereas, the fill factor of benzoic acid fullerene bis adducts (BAFB) is $69.10 \%$. We have worked surface passivation on the perovskite surface using a dicarboxylic group on the fullerene. The carboxylic group may form a hydrogen bond with

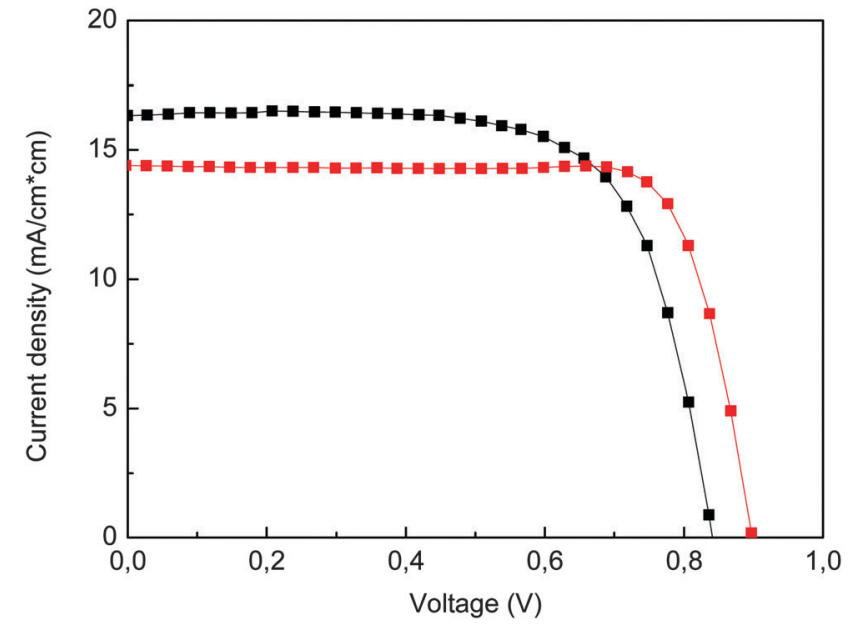

Fig. $6 \mathrm{~J}-\mathrm{V}$ curves of ITO/PEDOT/ $\mathrm{CH}_{3} \mathrm{NH}_{3} \mathrm{Pbl}_{3} / \mathrm{PCBM} / \mathrm{ZnO} / \mathrm{Ag}$ solar cells (red) and ITO/PEDOT/ $\mathrm{CH}_{3} \mathrm{NH}_{3} \mathrm{Pbl}_{3} / \mathrm{BAFB} / \mathrm{ZnO} / \mathrm{Ag}$ solar cells (black) under simulated $A M 1.5$ solar irradiation at $100 \mathrm{~mW} \mathrm{~cm}^{-2}$.
Table 2 Photovoltaic performance of perovskite solar cells

\begin{tabular}{llllr}
\hline & $J_{\mathrm{sc}}\left(\mathrm{mA} \mathrm{cm}^{-2}\right)$ & $V_{\text {oc }}(\mathrm{V})$ & FF & \multicolumn{1}{c}{$\eta(\%)$} \\
\hline BAFB & $16.2 \pm 0.11$ & $0.822 \pm 0.01$ & $69.1 \pm 1.5$ & $9.21 \pm 0.42$ \\
PCBM & $15.3 \pm 1$ & $0.868 \pm 0.03$ & $76.4 \pm 3$ & $10.13 \pm 0.14$ \\
\hline
\end{tabular}

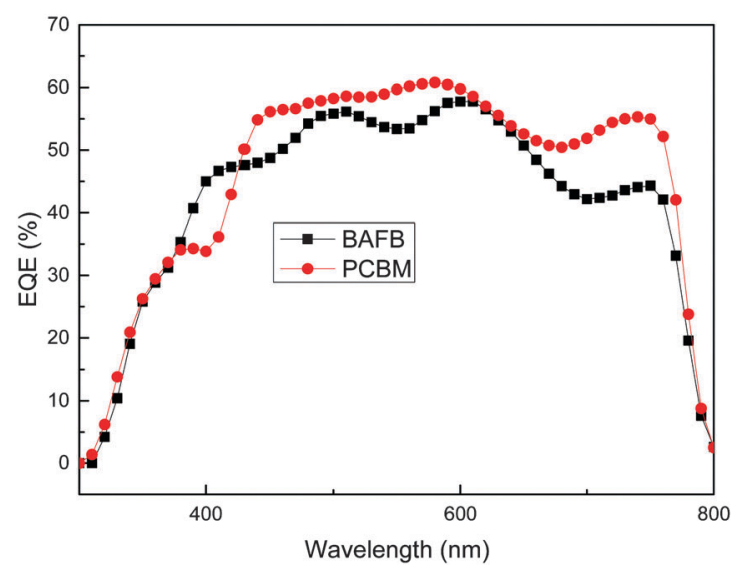

Fig. 7 The external quantum efficiency (EQE) curves of ITO/PEDOT/ $\mathrm{CH}_{3} \mathrm{NH}_{3} \mathrm{Pbl}_{3} / \mathrm{PCBM} / \mathrm{ZnO} / \mathrm{Ag}$ solar cells (red) ITO/PEDOT/CH $\mathrm{NH}_{3} \mathrm{Pbl}_{3} /$ $\mathrm{BAFB} / \mathrm{ZnO} / \mathrm{Ag}$ solar cells (black).
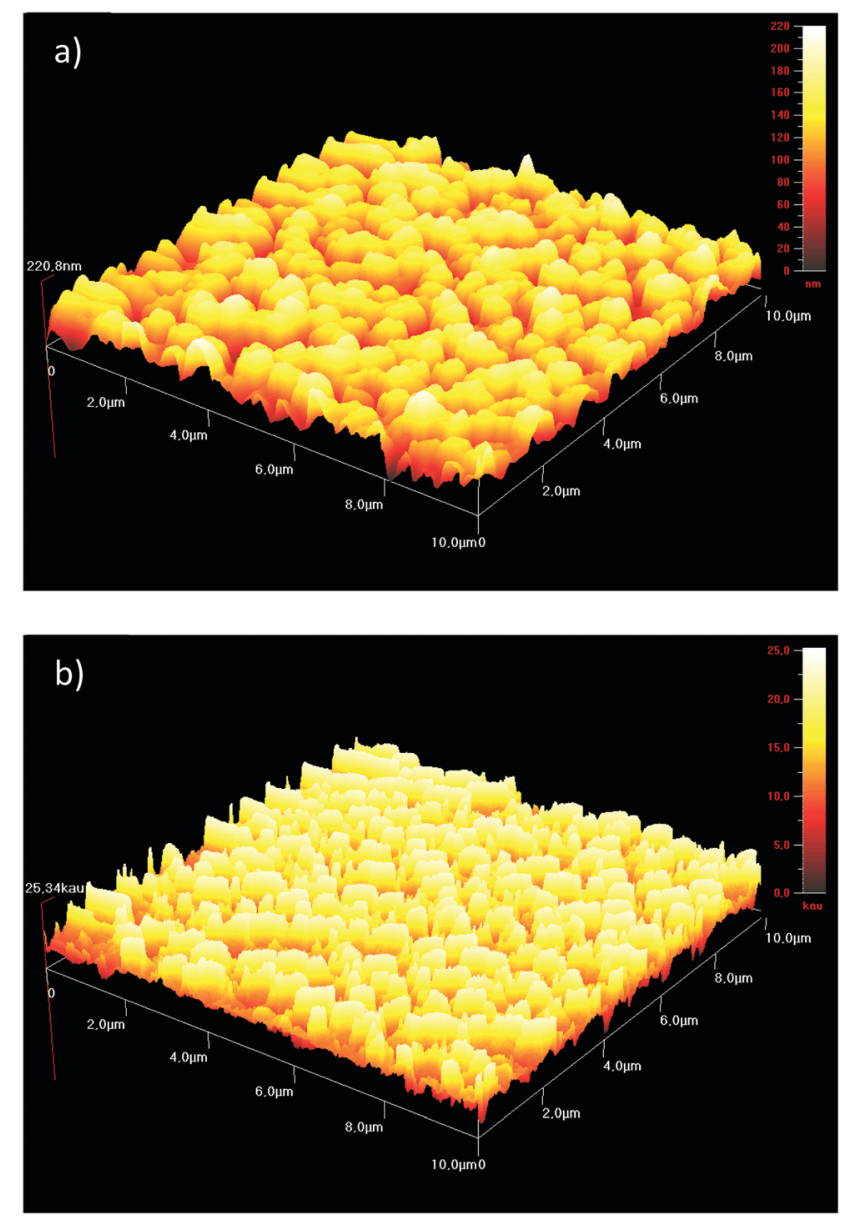

Fig. 8 AFM picture of the ITO/PEDOT/perovskite/BAFB/Ag device, in wave mode (a) and in phase mode (b). 
an $\mathrm{I}^{-}$ion in the perovskite and passivate the surface of perovskite, thus reducing the recombination. ${ }^{33}$ Our results show that the efficiency of reference perovskite bulk heterojunction solar cells using PCBM is higher than 1.066 times that of perovskite heterojunction solar cells using benzoic acid fullerene bis adducts (BAFB). The short circuit current, the open circuit voltage and other parameters which obtained from BAFB and reference PCBM perovskite heterojunction solar cells were tabulated with error bars for better photovoltaic performance comparisons in Table 2. Also, the external quantum efficiency (EQE) spectrum is presented for BAFB and PCBM materials in Fig. 7. The EQE spectrum gives us information about the response of the active layer upon illumination with the monochromatic light in a large range of wavelengths. In the EQE spectrum, a 55\% efficiency is shown in the range between $400-800 \mathrm{~nm}$. The EQE efficiencies of BAFB and PCBM materials are equal at $600 \mathrm{~nm}$. The panchromatic nature of the active layer was demonstrated in the EQE spectrum. Fig. 8 shows the atomic force microscopy image (AFM) of the device structure (ITO/PEDOT:PSS/perovskite/BAFB/ZnO/Ag) in wave mode (a) and phase mode (b). The AFM image also depicts a uniform deposition along the length of the device. The rms value of the perovskite heterojunction solar cell device was found to be $11.84 \mathrm{~nm}$.

\section{Conclusion}

In conclusion, novel fullerene material based heterojunction perovskite solar cells have been studied. Full material characterization studies of BAFB were also supplied $\left({ }^{1} \mathrm{H}\right.$ NMR, ${ }^{13} \mathrm{C}$ NMR and mass spectra). Optical, electrochemical and photovoltaic properties were also investigated. Though the absolute conversion efficiency reported here are well below those of solid state dye sensitized solar cells, this novel BAFB material represents a promising efficiency for perovskite heterojunction solar cells because of its close solar cell efficiency to phenyl-C61-butyric acid methyl ester material. We investigated the replacement of the phenyl-C61-butyric acid methyl ester material with this novel benzoic acid fullerene bis adduct (BAFB) compound. Our results show that the efficiency of benzoic acid fullerene bis adduct (BAFB) based perovskite heterojunction solar cells is $9.63 \%$ and a short circuit current density is $16.2 \mathrm{~mA} \mathrm{~cm}^{-2}$. Phenyl-C61-butyric acid methyl ester based perovskite heterojunction solar cells displayed an efficiency of $10.27 \%$ and a short circuit current density of $15.3 \mathrm{~mA} \mathrm{~cm}^{-2}$.

\section{Acknowledgements}

We acknowledge the Alexander von Humboldt Foundation (AvH), Deutscher Akademischer Austauschdienst - DAAD, Turkish Scientific and Technological Research Council (TUBITAK), UNESCO-LOREAL Foundation and Turkish Academy of Sciences (TUBA).

\section{Notes and references}

1 A. Kojima, K. Teshima, Y. Shirai and T. Miyasaka, J. Am. Chem. Soc., 2009, 131, 6050-6051.
2 H. J. Snaith, J. Phys. Chem. Lett., 2013, 4, 3623-3630.

3 W. Li, J. Li, L. Wang, G. Niu, R. Gao and Y. Qiu, J. Mater. Chem. A, 2013, 1, 11735-11740.

4 J. H. Rhee, C. C. Chung and E. W. G. Diau, NPG Asia Mater., 2013, 5(e68), 1-17.

5 Z. Ku, Y. Rong, M. Xu, T. Liu and H. Han, Sci. Rep., 2013, 3, 3132 .

6 S. Volker, S. Collavini and J. L. Delgado, ChemSusChem, 2015, 8, 3012-3028.

7 B. V. Lotsch, Angew. Chem., Int. Ed., 2014, 53, 635-637.

8 J. Seo, S. Park, Y. C. Kim, N. J. Jeon, J. H. Noh, S. C. Yoon and S. I. Sang, Energy Environ. Sci., 2014, 7, 2642-2646.

9 P. W. Liang, C. Y. Liao, C. C. Chueh, F. Zuo, S. T. Williams, X. K. Xin, J. J. Lin and A. K. Y Jen, Adv. Mater., 2014, 26, 3748-3754.

10 S. D. Stranks, G. E. Eperon, G. Grancini, C. Menelaou, M. J. P. Alcocer, T. Leijtens, L. M. Herz, A. Petrozza and H. J. Snaith, Science, 2013, 342, 341-344.

11 G. Xing, N. Mathews, S. Sun, S. S. Lim, Y. M. Lam, M. Graetzel, S. Mhaisalkar and T. C. Sum, Science, 2013, 342, 344-347.

12 S. Pang, H. Hu, J. Zhang, S. Lv, Y. Yu, F. Wei, T. Qin, H. Xu, Z. Liu and G. Cui, Chem. Mater., 2014, 26, 1485-1491.

13 Q. Lin, A. Armin, R. C. R. Nagiri, P. L. Burn and P. Meredith, Nat. Photonics, 2015, 9, 106-112.

14 J.-H. Im, C.-R. Lee, J.-W. Lee, S.-W. Park and N.-G. Park, Nanoscale, 2011, 3, 4088-4093.

15 H. S. Jung and N.-G. Park, Small, 2015, 11, 10-25.

16 H. P. Zhou, Q. Chen, G. Li, S. Luo, T. B. Song, H. S. Duan, Z. R. Hong, J. B. You, Y. S. Liu and Y. Yang, Science, 2014, 345, 542-546.

17 Q. Chen, H. Zhou, Z. Hong, S. Luo, H. S. Duan, H. H. Wang, Y. Liu, G. Li and Y. Yang, J. Am. Chem. Soc., 2014, 136, 622-625.

18 I. Chung, B. Lee, J. He, R. P. H. Chang and M. G. Kanatzidis, Nature, 2012, 485, 486-498.

19 J. Burschka, N. Pellet, S.-J. Moon, R. Humphry-Baker, P. Gao, M. K. Nazeeruddin and M. Graetzel, Nature, 2013, 499, 316-320.

20 H.-S. Kim, C.-R. Lee, J.-H. Im, K.-B. Lee, T. Moehl, A. Marchioro, S.-J. Moon, R. Humphry-Baker, J.-H. Yum, J. E. Moser, M. Graetzel and N.-G. Park, Sci. Rep., 2012, 2, 591.

21 M. M. Lee, J. Teuscher, T. Miyasaka, T. N. Murakami and H. J. Snaith, Science, 2012, 338, 643-647.

22 J. H. Heo, S. H. Im, J. H. Noh, T. N. Mandal, C.-S. Lim, J. A. Chang, Y. H. Lee, H.-J. Kim, A. Sarkar, M. K. Nazeeruddin, M. Graetzel and S. I. Seok, Nat. Photonics, 2013, 7, 487-492.

23 G. Hodes, Science, 2013, 342, 317-318.

24 S. Erten-Ela, J. Brendel and M. Thelakkat, Chem. Phys. Lett., 2011, 510(1), 93-98.

25 E. Edri, S. Kirmayer, A. Henning, S. Mukhopadhyay, K. Gartsman, Y. Rosenwaks, G. Hodes and D. Cahen, Nano Lett., 2014, 14, 1000-1004.

26 V. Gonzalez-Pedro, E. J. Juarez-Perez, W.-S. Arsyad, E. Barea, F. Fabregat-Santiago, I. Mora-Sero and J. Bisquert, Nano Lett., 2014, 14, 888-893.

27 Y. S. Kwon, J. Lim, H.-J. Yun, Y.-H. Kim and T. A. Park, Energy Environ. Sci., 2014, 7, 1454-1460.

28 A. Mei, X. Li, L. Liu, Z. Ku, T. Liu, Y. Rong, M. Xu, M. Hu, J. Chen, Y. Yang, M. Grätzel and H. Han, Science, 2014, 345, 295-298. 
29 (a) S. Erten and S. Icli, Inorg. Chim. Acta, 2008, 15, 595-600; (b) S. Erten-Ela, S. Cogal, G. Turkmen and S. Icli, Curr. Appl. Phys, 2010, 10, 187-192; (c) G. Turkmen, H. Sarica and S. Erten-Ela, Solid-State Electron., 2014, 100, 61-70.

30 J. Y. Xiao, J. J. Shi, D. M. Li and Q. B. Meng, Sci. China: Chem., 2015, 58, 221-238.

31 J. B. You, Z. R. Hong, Y. Yang, Q. Chen, M. Cai, T. B. Song, C. C. Chen, S. R. Lu, Y. S. Liu, H. P. Zhou and Y. Yang, ACS Nano, 2014, 8, 1674.
32 (a) D. Baran, S. Erten-Ela, A. Kratzer, T. Ameri, C. Brabec and A. Hirsch, RSC Adv., 2015, 79(5), 64724-64730; (b) S. Erten-Ela, C. Villegas, J. L. Delgado and N. Martin, New J. Chem., 2015, 39, 1477-1482; (c) H. Zhou, Q. Chen, G. Li, S. Luo, T. Song, H. S. Duan, Z. Hong, J. You, Y. Liu and Y. Yang, Science, 2014, 345, 542-546.

33 X. Li, M. I. Dar, C. Yi, J. Luo, M. Tschumi, S. M. Zakeeruddin, M. K. Nazeeruddin, H. Han and M. Grätzel, Nat. Chem., 2015, 7, 703-711. 